Article

\title{
The Noborder Movement: Interpersonal Struggle with Political Ideals
}

\author{
Leslie Gauditz ${ }^{1,2}$ \\ ${ }^{1}$ SOCIUM Research Center on Inequality and Social Policy, University Bremen, 28359 Bremen, Germany; \\ E-Mail: gauditz@uni-bremen.de \\ 2 BIGSSS Bremen Graduate School of Social Sciences, University Bremen, 28359 Bremen, Germany
}

Submitted: 31 March 2017 | Accepted: 14 August 2017 | Published: 19 September 2017

\begin{abstract}
Over the last decade, self-organized refugee protests in Europe have increased. One strand of activism in Europe, noborder, involves a transnational network of people who are heterogeneous with regards to legal status, race, or individual history of migration, but who share decolonial, anti-capitalist ideals that criticize the nation-state. Noborder activists embrace prefigurative strategies, which means enacting political ideals in their everyday life. This is why this article asks: How do noborder activists try to meet their political ideals in their everyday practices, and what effects do these intentions entail? Noborder practices take place at the intersection of self-organization as a reference to migrants' legal status or identity, on the one hand, and self-organization as anti-hierarchical forms of anarchist-autonomous organization, on the other. On the basis of empirical findings of a multi-sited ethnography in Germany and Greece, this article conceptualizes that noborder creates a unique space for activists to meet in which people try to work productively through conflicts they see as being produced by a global system of inequalities. This demanding endeavor involves social pressure to self-reflect and to transform interpersonal relationships. Broader society could learn from such experiences to build more inclusive, heterogeneous communities.
\end{abstract}

\section{Keywords}

activism; asylum; everyday politics; noborder; prefiguration; protest; refugee protest; self-organization; social movements

\section{Issue}

This article is part of the issue "Perspectives on the European Border Regime: Mobilization, Contestation, and the Role of Civil Society", edited by Ove Sutter and Eva Youkhana (University of Bonn, Germany).

(C) 2017 by the author; licensee Cogitatio (Lisbon, Portugal). This article is licensed under a Creative Commons Attribution 4.0 International License (CC BY).

\section{Introduction}

Over the last decade, refugee protests in Europe increased to the surprise of both politicians and civil society. One specific strand of activism, noborder, involves a transnational network of people who are heterogeneous with regards to legal status, race, gender, or individual history of migration, but who share a post-colonial, anticapitalist ideology that criticizes the nation-state.

Research studying refugee protest combines migration research with social movement studies, focusing on protest repertoire and political strategy (e.g., Ataç, Rygiel, \& Stierl, 2016; Klotz, 2016; Tyler \& Marciniak, 2013). The literature regarding internal, relational processes in the movement has been growing (e.g., Blumberg \& Rechitsky, 2015; English, 2017; King, 2016; Millner, 2011; Rigby
\& Schlembach, 2013). I build up on these studies' insights on the beauty and difficulty of building solidarity networks between people who differ in their self-definition (i.e., as refugee, undocumented, citizen, privileged, person of color, activist, volunteer). Moreover, I contribute to the literature, in discussing noborder's heterogeneity as well as on the conflicts emerging from it and on activists' practices in attempting to resolve them.

Noborder embraces prefigurative strategies, which means that activists' everyday practices should match the radically egalitarian goals of the movement. This is no small feat, which is why this article asks:

In what ways do noborder activists try to meet their political ideals in their everyday practices, and what effects do these intentions entail? 
Data collection was conducted in Germany and Greece from 2013 to 2017 through a multi-sited ethnography. With reference to the border-regime analysis (Hess \& Tsianos, 2010), this involved tracking and tracing the research subject through various sources of dataparticipatory observation, interviews, and online documents that activists produced. Data was coded and mapped by applying the tools of Situational Analysis (Clarke, 2005). This article adopts a reflexive approach, the methodological reason being the author's involvement within the field.

The article argues that noborder's activism provides relational spaces for productive interpersonal struggles. Based on my data and experiences, I believe that a systematic analysis of difficult learning processes taking place in activist contexts is something that European societies can learn from more broadly. Insights presented in this article are no insular achievement, but part of a collective effort by activists and scholars to understand contemporary political practice.

The article proceeds as follows: First, the methodology of Situational Analysis and my position as the author is presented. Then a description of noborder activism is provided, together with a discussion of its involvement with refugee protest and anarchism. Thereafter, activist's discussion on 'privilege' is elaborated on, together with the analytical logic of prefigurative politics. Finally, I critically describe practices and social pressures inside noborder spaces.

\section{Methodology and Positionality of the Author}

As will be described in detail below, noborder's ideology is radically egalitarian, promoting the freedom of movement for everybody. Activists try to meet this ideal through anti-hierarchical practices. To investigate this, it is necessary to look at their everyday practices of direct action, collaboration, and relationships.

Between 2013 and 2017 I conducted multi-site research in Germany and Greece-in the context of an MA thesis and a PhD project. At the time of writing, data consists of 35 research diary entries (2015-2017), 21 halfstructured interviews with people of different positionalities at various German and Greek cities (2013-2017) and multiple participatory observations mainly in Hamburg, Athens, and Lesvos. In addition, I collected online representations and public statements of noborder projects.

To analyze such varied data, tools were used from postmodern Grounded Theory, the Situational Analysis (SA) developed by Adele Clarke (2005). SA infers theoretical concepts from empirical data using the logic of abduction. This involves a circular research process of coding textual and visual documents and mapping the most salient elements of a field situation. SA is based on the interpretative methodological premise (Yanow \& SchwartzShea, 2013) that there is no 'neutrality' of science and that each instance of knowledge production is particu- lar and shaped by structural and individual factors. The method is developed to be sensitive to power issues in the field and calls for researchers' engaged reflexivity.

The research perspective is always conducted from my position, having been born a white, female, German citizen from a middle-class family. I have been involved in refugee support since 2009. Seeing and understanding the exclusionary and restrictive system of asylum in Germany came as a shock and I grew to identify myself as part of the anti-racist scene. My research is motivated by wanting to understand this activism, which followed some different rules than those I grew up with, and why engaging in it appears to me worthwhile.

Data collection was conducted in ways which protect research participant's privacy and health as much as possible. Where necessary, events and sites are anonymized. Interviewees deliberately decided how they wanted to be represented. ${ }^{1}$ They were informed about the broad research interest of the study. As SA involves a circular research process, the pre-determined research question, which guided data collection, was later modified according to the emphasis made by interviewees.

\section{Noborder Activism in Europe}

It is nearly impossible to join a demonstration related to refugees without overhearing the chant "No border, no nation," often accompanied by a hearty "Stop deportation!" But noborder is more than a popular slogan. Over the last 20 years, a critical normative framework informed a network of activist groups engaging in anarchist-autonomous practices.

Literature has largely discussed noborder politics, denoting the struggle for freedom of movement (Anderson, Sharma, \& Wright, 2012; Burridge, 2015; King, 2016; Loyd, Mitchelson, \& Burridge, 2012; Walters, 2006). Noborder politics criticize the legitimacy of nation-states and their borders that restrict human mobility based on citizenship. Classically, citizenship in social sciences is discussed as ensuring legal rights and access to social benefits in the tradition of T. H. Marshall. However, from a decolonial perspective, the rights and privileges of citizenship are based on exclusion and exploitation of people in the global south. The social inequalities produced by this are inherited and highly racialized (Boatcă, 2015).

Noborder activists have a difficult relationship with nation-states because they embrace this decolonial analysis. From this perspective, Western migration and asylum policies restrict people's freedom and produce classifications of humans as il/legal or (un)documented. In contrast, activists point out that humans have always migrated. They consider migrants not as problematic for national cohesion, but as productive humans whose potentials are constrained by it (Anderson et al., 2012, p. 74). Activists see Western capitalist states as being responsible for the welfare of migrants, due to their exploitation

\footnotetext{
${ }^{1}$ Anonymized names are marked through * when first mentioned.
} 
of resources in Africa or involvement in warfare which has often lead to forced migration (Walters, 2006).

Noborder activists, therefore, distrust nation-state institutions, parties, and the police. The will to do politics beyond the logic of the state, but the real need to at least partly engage with it, is a central dilemma of noborder as Natasha King (2016, p. 57f.) insightfully argues.

In their struggle for the freedom of movement, noborder politics employs direct action. The protest repertoire includes demonstrations, hunger strikes, blockages, occupation or civil disobedience, especially against detention camps or deportations. Noborder activists engage in campaigns against restrictive immigration and refugee policies and are involved in protest camping (see below).

\subsection{Historical Development of the Noborder Movement}

The noborder movement began in the late 1990s in Europe and expanded quickly, reaching as far as the Americas. The first group to articulate noborder politics, according to Anderson et al. (2012, p. 83), was the so-called, 'sans-papiers movement' in France. The 'sans-papiers' ('without papers') are undocumented migrants who have continuously and visibly sought to claim their recognition of rights since 1996, demanding policy changes in spite of the fact that they were not citizens (Cissé, 1996). They inspired the founding of the so-called 'noborder network' in 1999. This network connects groups involved with migrant rights in central Europe, such as NoOnelslllegal (Kopp \& Schneider, n.d.). Members mainly identified as 'anti-racist', a strand of left-wing activism connected to the anti-fascist or autonomous movement. However, many were white people without a history of forced migration. Noborder activities then connected groups with different compositions of racial identity and legal status.

Today, the noborder movement transversally extends throughout Europe and beyond, with loose and tight connections between local groups, as well as transregional organizations such as Afrique-Europe-Interact or Welcome2Europe.

In 2015, significant numbers of refugees in Europe led to increased mobilization, for and against, migration-meanwhile, the noborder movement grew. The international 'noborder kitchen' collective on Lesvos has been feeding hundreds of people per day, while the 'noborder school' in Athens has been teaching languages and consensus decision-making.

The noborder movement is heterogeneous. Noborder politics in Europe mostly focus on the topic of refugees, but the movement is not necessarily linked to people who are juridically or discursively framed as such. It includes people of different race, gender, religion, and countries of origin. People engage in the movement who may or may not identify themselves as being refugees, migrants, or activists, and who may come from very dif- ferent political and socio-economic backgrounds. They speak and read different languages, with educational levels ranging from illiterate to degree-holders. Their diverse upbringings entail differing societal and political norms and values. Legal statuses range from European citizen, precarious status, to 'being undocumented'.

\subsection{The Double Meaning of Self-Organization}

A prevalent use of the term self-organization in the movement caught my attention. Considering the diversity in the field, I wondered who the 'self' was. To my knowledge, it has not been systematically discussed-either in former studies or in the field-that self-organization in noborder has at least two meanings. ${ }^{2}$

Firstly, self-organization describes horizontal forms of organization used by anarchist or autonomous movements. For example, Platanos, a non-state refugee camp on the island of Lesvos, calls itself "Self Organized Forefront Solidarity Structure for Refugees". This means that it is anti-hierarchically structured without close connection to governments.

Secondly, 'self-organized refugee protest' indicates that people who identify as refugees or (undocumented) migrants are organizing and planning protests on their own behalf, instead of being represented by citizen activists. The year 2012 marked the beginning of a new cycle of protest around refugee and migration topics, in which refugees themselves visibly protested (Ataç et al., 2016). The Voice, a self-organized refugee group founded in the 1990s, put the slogan "We are here because you destroy our countries" on the left-wing agenda (Jakob, 2016, pp. 20-27). Noborder groups have been featuring this slogan prominently ever since.

Both logics of self-organization intermingle in noborder. Autonomous-anarchist self-organization encourages individual empowerment and criticizes representative democracy. This, I suggest, is why citizens of this political socialization took refugees' demands to represent themselves seriously, increasing cooperation. This cooperation makes up the movement, and "creates something new in anarchism" (King, 2016, p. 187).

\section{Privilege and Solidarity}

Still, the division remains between those who engage in protest because of their own material conditions and those who relate to it through inclusive values. From a noborder perspective, this cannot be perceived as neutral, but rather as creating inequalities. Mixed organizations are repeatedly and controversially discussed in the field of pro-migrant movements. Some view them as necessary, as citizens are able to mobilize resources for migrants. Others regard truly equal cooperation as being impossible and therefore opt for separated agitation.

According to King, this is a key dilemma noborder activists face (2016, p. 60). In analytically understanding

\footnotetext{
${ }^{2}$ For a related discussion of 'autonomy' see King (2016, p. 96f).
} 
the inequalities reproduced within the noborder movement itself, the discussion on privilege is important for activists (King, 2016, p. 190; Millner, 2011).

Privilege refers to those characteristics that confer advantage or disadvantage to people, rendering them viable empowered subjects or vulnerable ${ }^{3}$ (Millner, 2011, p. 326). Its problematic nature stems from the fact that its possession is no individual achievement or failure but it is generally inherited and inscribed in a global, social order of power. In noborder, privilege mainly comes down to the intersectional triad of racism, sexism, and capitalism (English, 2017), with religion and sexuality being increasingly involved. For example, racism or islamophobia influence one's possibilities to engage in paid labor or move within countries just as legal status does. Such difficulties are multiplied for women.

Privileges define borders, meaning not only a state's territory but mental and embodied borders, too. When people of different privileges cooperate in political action, conflicts can emerge. They hinder friendship, romance, and egalitarian working relations, binding people in asymmetric relationships instead in which they are "simultaneously separated by and bound together...by the violence of the border imperialism" (Walia, 2013, p. 6).

In the noborder context, it means that only those privileged 'supporters' who see their interconnectedness of a struggle for freedom for all are welcome. In 2012 , in reaction to conflicts at a noborder event in Cologne, diverse activists put together a brochure. Its title references a quote of American indigenous activist Lilla Watson: "If you've come here to help me, you're wasting your time. But if you've come because your liberation is bound up with mine, then let us work together" (Watson, cited by transact, 2014, p. 25). By choosing that quote to explain their own conflicts, activists can be interpreted as seeing themselves as a part of a global fight against systemic inequality, or as a non-refugee in Greece put it:

Solidarity means that we understand that we are victims of the same politics. We are victims of poverty, of underestimating the value of our labor....That is why we show solidarity for those people, because we belong to the same class. (Mohammed*)

From this perspective, core conflicts are not interpreted as merely individual, but as an effect of the system. As I understand it, noborder's logic is thus: when conflicts are not individual, the answers cannot be individual either. Developing practical answers is a collective effort of learning, in which privileged and non-privileged people have to engage together to overcome inequality and to be able to meet each other in an authentic way.

\subsection{Recurring Key Conflicts}

So, what are everyday issues within noborder which lead to conflict? Numerous case-studies (Blumberg \& Rechitsky, 2015; Burridge, 2010; English, 2017; King, 2016; Rigby \& Schlembach, 2013) and activist accounts of events and discussions (Cissé, 1996; Lang \& Schneider, n.d.; transact, 2014) tell us about recurring issues within noborder, all of which were present during my field work. In the limited scope of this article, I focus on three issues which mainly emerge from different histories of migration but which are specific in the inequality that they demonstrate which is tackled by norms of selforganization ${ }^{4}$. They are:

- who speaks for whom;

- language barriers;

- risk-taking during protest action.

The issues overlap. Language barriers appear when people do not share mother tongues. Using only one (hegemonic) language can cause separation and can be perceived as disrespectful. Translation becomes a powerful tool. Engagement in protest action involves differing risks according to a person's position, for example, undocumented people within demonstrations are in danger of being registered by the police, which could lead to deportation.

It is common, that privileged activists dominate public discussions, appeals to the state, and internal decisionmaking processes. Self-organized refugee protests show that speaking up for themselves is pivotal for non-citizen activists, who have limited possibilities to formally participate in the political system which they are subject to. By refusing representation, they ensure that they can shape actions according to their needs and knowledge.

\subsection{Approaching Conflicts the Anarchist Way: Prefigurative Politics}

In the above text, I have argued that developing solutions for conflict between people of different statuses is a collective effort in noborder. However, solutions are put into place at the individual level. What may seem to be a paradox is understandable through the logic of prefigurative politics.

Noborder has developed in parallel to other contemporary social movements which follow horizontal principles of organization. Like alter-globalization, the Zapatistas or Occupy, noborder is marked by a flexible, network-based structure of self-organization, relatively autonomous from political parties, trade unions, and other state institutions (Juris \& Khasnabish, 2013, pp. 378-381). Activists in such movements follow a dual

\footnotetext{
${ }^{3}$ Where to draw the line between 'privileged' and 'non-privileged' is context specific, as refugees with long-term residency can be privileged against undocumented migrants etc.

${ }^{4}$ In reality they are never fully separated from the other topics. For a discussion of the entanglement of race and gender in the creation of safer spaces, see English (2017).
} 
political strategy of challenging state policies and simultaneously creating spaces to establish and experience new practices of sociality within the sphere of daily social life (Juris \& Khasnabish, 2013, p. 378).

This political strategy is also known as prefiguration. The term was coined by Carl Boggs (1977) to denote those social movement practices, which aim at creating a desired sociality-e.g., a world without borders-not in the future, but in day-to-day practice.

The logic of prefigurative politics contrasts with the common understanding of politics as state processes. Many noborder actors don't even view what they do as being political or activism:

In 2015, the Kampnagel Theater in Hamburg hosted a performance art project in which five refugees of the Lampedusa activist group in Hamburg lived in a temporary house for five months. The house was an open space allowing them to get in contact with the neighborhood. Martha*, one of the house's inhabitants, a black women in her thirties told me that she did not perceive this as 'political', a word she associated with political parties for whom she seems to have developed mistrust throughout the group's struggle for a right to stay. Rather, she saw the potential for everyday interactions in the project. She enjoyed hosting meals for Germans as a means of getting to know them, their tastes and mannerisms. As Martha explained to me:

[T] he child has to crawl before it walks. The solidarity program here in the [house] is just a starting point. So it had its ups and downs, but we believe next winter it will be better, or at least we were able to show that we believe in ourselves... what we can do. (Martha)

An analysis, which is led by the concept of prefiguration, sees it as a political act that they demonstrate their abilities. Prefiguration means that an inner, personal transition is necessary to achieve a change in the political system. It means continuously trying out new things in an attempt to improve these experiences. Or as activists from the refugee squat City Plaza in Athens said: They have no solutions, only answers. Meaning, they don't have perfect solutions for the world's problems, but they try to answer concrete problems directly and to be self-organized in the best way they can.

Overall, noborder practices must be viewed as efforts to find answers to contemporary human mobility which are different to those proposed by NGOs, intergovernmental organizations (such as UNHCR) and political parties.

Ethnographic research emphasizes the demarcation of noborder actors from 'humanitarian aid'. Such a demarcation is usually made while framing strategies and actions (e.g., King, 2016; Millner, 2011; Rigby \& Schlembach, 2013). Noborder-activism is defined as 'solidarity' in contrast to humanitarian 'help' or 'charity', which for noborder implies a hierarchically stratified relationship between those who give and those who receive.
Noborder activists view this as maintaining borders between people.

Mohammed, who got in touch with anarchism in his twenties in Greece having grown up in a conservative Middle East household, told me his opinion:

I/we dream about a stateless society. Well, not only dreaming we are making it happen...each day, each action we do is about this, but we realize it is not something easy....I would not say philanthropy or charity or activism. It is part of a struggle for a classless, stateless society....That's how we see it. (Mohammed)

This quote shows how Mohammed, who can analytically be defined as an activist because of his transformative goal, does not define himself as such. But more importantly, he realizes that the prefigurative struggle is not easy. In fact, there is a salient concern in the movement: that the direct cooperation between people of differing privilege is marked by the same paternalist structures it tries to overcome. The following will discuss this concern and the effect of the social pressure it produces.

\section{Spaces of Learning}

It was outlined above that noborder tries to meet a radical egalitarian ideal through prefigurative politics. In collaborations beyond mental, embodied and state borders, the noborder movements tries to find answers to human mobility which they perceive as being alternatives to those of contemporary mainstream political actors such as NGOs, intergovernmental organizations, and politicians. I further described some issues that cause conflict which are debated at the intersection of anarchist and refugee self-organization.

This article questions what the effects are of activists' attempts to meet egalitarian ideals in their everyday action, be they intentional or unintentional. I argue that one effect is that, in noborder, heterogeneous activists open up specific relational spaces in which many individuals and groups are willing to engage in conflict productively and develop different answers.

Effectively every interaction can trigger learning processes, but activists' actions have established concrete relevant sites in which experiences intensify. These being: collaborative protest action, self-organized conferences, and most importantly, noborder camps and squatted buildings or public squares.

Noborder camps are temporary camp sites of hundreds of people in which refugees, other migrants, and non-migrants meet to engage in education, networking and the planning of protest action. Every year since 1998, at least one camp, has been organized in Europe and beyond. From the beginning, the "dark side of camping" (Lang \& Schneider, n.d.) revealed how inequalities between people of different privilege were maintained against the better wishes of activists, who were actively engaged in the struggle against inequality. 
Experiences of temporary camping are translated into squatting. ${ }^{5}$ A prominent example being the City Plaza hotel in Athens, squatted in 2016. At the time of writing, four hundred refugees lived in a "self-organized" manner together with non-refugee activists. This is no casual project, but a result of network-building over decades. For example, on an actor level, the foundation of the Trans-European Welcome2Europe network which sustains City Plaza can be traced back to the 'noborder camp' in Lesvos in 2009.

\subsection{Practices Inside the Spaces}

In the following, I briefly illustrate practical answers to the issues of conflict described above.

Imagine a squatted square or building in a European city. Citizen activists gather and people who irregularly migrated to Europe live there. Journalists want an interview, approaching the European, white activists. But they often refuse, to ensure that a more varied selection of people-or even just migrants alone-speak to the media.

Decisions have to be made on how to clean up, get food, where to demonstrate, what public statements to make. They are made in regular plenaries where people sit in circles and discuss. Privileged people can be asked to talk less or even leave the room if they dominate discussions.

Perhaps, a rally is planned to protest the detention of undocumented migrants. Asking who wants to be on the street is part of carving out strategies. Information on the risks according to a person's position are gathered and then everyone is supposed to decide for themselves.

Translation chains are in place. People sit in groups, focused around those who speak two or more necessary languages, whispering translations of what a speaker says. Instead of having paid translators, this is a horizontal, reciprocal practice in which the same person can quickly switch from translating to listening. Longer chains, e.g., are from Greek to English to Farsi to Arabic (and back). The length of a chain is mostly constrained by time because it is important to pause a discussion for the translator to finish. Controlling one's speed of speaking, and making sure others do so during heated discussions, becomes a symbol of respect to those who do not speak a dominant language.

Written communication is circulated in as many relevant languages as possible, but translations are mostly available for longer statements as opposed to fast discussions. Often mailing lists are used, a common tool of communication by activists, because they are of lowcost and are regarded to be horizontal. However, the medium has undesired exclusionary effects, as it strongly favors those who are verbal and literate. Furthermore, people in precarious living situations do not often own laptops which enable easier access to long emails or attachments. As smartphones become more widespread, groups in instant-messengers increase in relevance. Still, a combination of online and offline communication, which includes diverse people and nonverbal interaction, is necessary to engage people in mobilization and to build trust.

Finally, activists cooperate with other refugee groups, preferring those which are inclusive and self-organized. In 2015 and 2016, Syrian refugees had privileged entry to central Europe. This caused conflict between Syrians and migrants from other countries. Noborder activists promote freedom of movement for all migrants and reject working with selective groups.

\subsection{Social Pressure and Emotion Management}

Such practices do not produce perfect solutions; rather, their enactment is based on trial and error. Activists I spoke with, demonstrated a devotion to social change combined with high expectations of interpersonal behavior. But often things don't work out. For example, activists of the self-organized refugee camp PIKPA on Lesvos struggled with a Syrian group who had co-opted a cemetery exclusively for people of their belief, leaving the noborder activists at loss about how to react. In such situations when expectations are not met, emotional reactions including disappointment, frustration, and anger likely develop. They might even cause further conflicts.

Emotion management is expected when the causes of conflict are seen in the distribution of privilege. The activist strategy to be able to identify conflicts caused by borders and to be able to transform them is selfreflection of privilege (e.g., Millner, 2011, p. 326). For example, for white people, it is more difficult to see everyday racism, and men with any citizenship should consciously learn to consider the psychological effects of patriarchy.

I want to illustrate this with an example from my own experience, where external social pressure was internalized. In 2013 and 2014 I attended workshops in which positionality was discussed. Still, in 2017 I found myself in a paternalistic situation when a former flat-mate who had been granted asylum in Germany, needed to find a new room. I found the young man's expectations of apartment size unrealistic and suggested alternative options. When he did not pursue these, I silently considered him ungrateful of my efforts, but I did not verbally blame him.

The activist way of seeing this conflict as external to the individual worked as a psychological strategy to let go of negative emotions. I learned that it is not sufficient to reflect on positionality verbally. Rather, dealing with its (emotional) effects is an ongoing process. Eventually, I understood how he strategically dealt with the constraints of the state's asylum system. I understood that I was frustrated because I felt useless, and I wanted him to take my advice in order to feel helpful. While he actively developed a network of support, he needed to make his own decisions and was quite capable of doing so.

\footnotetext{
${ }^{5}$ For further insights into the contemporary entanglement of migration and squatting see Mudu and Chattopadhyay (2017).
} 
Therefore, efforts to implement egalitarian ideals in everyday personal interaction often manifest in carefully controlled behavior. Accepting social pressure and adapting a self-reflective stance concerning one's own position of power-or discrimination-is necessary to be part of a noborder group and space.

\subsection{Seen from Outside}

I have often perceived noborder spaces as a sort of parallel world in which the rules and values are different to that of mainstream society. Strikingly, a French activist told me in 2016 that to him the anarchist migrant support in Athens felt like a recovery center for disappointed activists from other countries.

Prefiguratively, activists can try to set examples for people outside their own circles. Longtime Greek citizen activist Efi Latsoudis, described the self-organized refugee camp PIKPA on Lesvos as an example of better refugee housing and wondered if its existence might have actually fostered the huge international refugee support that emerged on the island after 2015.

However, activists' well-intentioned efforts of inner transition often manifest in a certain wariness of outsiders and newbies who have not yet been proven to have integrity, often mixed with an omnipresent (and rightful) fear of being infiltrated by state institutions. I assume this is why noborder activists repeatedly were described to me from 'the outside' as closed off and wearisome. Hannes*, a blond, tall German who, in 2015 , volunteered at a refugee support group at an urban train station, expressed annoyance at having been suspected of being an undercover policeman. He said he preferred less political contexts, as he feels there are fewer prohibitions. Also, the theater director of the refugee housing project mentioned above expressed surprise that the project was well received amongst the activists, because "from their perspective, you always can do something wrong" (Amelie).

Returning to the concept of prefiguration, this means that a shared learning process which may take place inside the movement is not apparent from outside.

This is relevant given the increase in refugee support after 2015 in Europe, which not only resulted in a proliferation of noborder but also in a wave of civic support in Central Europe in which the term 'welcome culture'

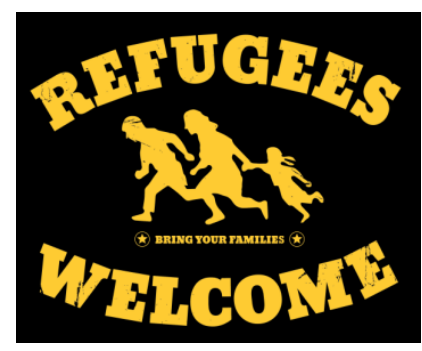

Figure 1. Refugees-welcome logo. Source: Linkes Grafik$\operatorname{archiv}$ (n.d.). was coined, picking up the logo of "Refugees Welcome" (see Figure 1), which had been produced in anti-racist contexts (Wallrodt, 2015).

However, the positive connotation of "Refugees Welcome" is critically discussed by refugee activists, who argue that 'welcoming' focused on citizens' efforts, and covered up immigrant self-organization (Omwenyeke, 2016). This could mean that experiences of a noborder struggle were not translated to the civic support actors.

\section{Conclusions}

This article attempted to answer the following questions: In what ways do noborder activists try to meet their political ideals in their everyday practices, and what effects do these intentions entail? It described the noborder movement's normative and practical foundations and the heterogeneous composition of its members.

The noborder movement emerges at the intersection of self-organized refugee and migrant protest and anti-hierarchical practices of organization in anarchoautonomous groups. In contrast to what the slogan suggests, noborder is not only 'against' something (the border), but in favor of building a world in which solidarity reaches beyond culture, religion, and citizenship. Activists try to meet their political ideals prefiguratively in horizontally organized practices of interaction that aim to provide authentic human encounters.

I suggest that noborder creates a unique space of activist engagement in which people attempt to work productively through conflicts they regard to be a product of a global system of inequalities. Spaces can open up in every daily interaction and do so at a larger scale at noborder camps, squats, and collaborative protest events.

Creating productive spaces is easier said than done, as idealistic goals are difficult to achieve in a world structured by inequality. The noborder movement includes a multiplicity of actor identities and legal statuses. Conflicts emerge along the lines of inequality, discussed in activist circles as the unequal distribution of privilege. It is embedded in the trial-and-error logic of prefiguration, where efforts can fail and reproduce top-down relations, causing frustration and anger. In such situations, social pressure compels activists toward emotional self-control and reflection with regards to their individual position of privilege. This is a never ending and complicated process but necessary to stay inside the noborder movement's circles. I interpret that this is one reason why noborder activism is often, at least from the 'outside', perceived as being closed-off and highly demanding.

There are two reasons for continuing research on noborder. First, since 2015, these spaces have been quantitatively multiplying and therefore affect an increasing number of people. Second, broader society could learn from the experiences within these spaces to build more inclusive, heterogeneous communities.

As a shared learning process inside noborder depends on interpersonal relationships and is complicated 
to communicate to more civic or state actors, future research could further investigate the lines of exclusion and how to enhance relationships between these groups.

\section{Acknowledgements}

The author deeply thanks everyone who donates their time to the struggle for freedom and equality, and especially those who spent valuable time sharing their experiences with her. She also thanks the editors of this thematic issue, the Colloquium "politics from below" in Berlin and three anonymous reviewers for their helpful comments. Fieldwork in Greece in 2016 was funded by an "Impulse Grant" of the University of Bremen's Central Research Development Fund, which the author gratefully acknowledges.

\section{Conflict of Interests}

The author declares no conflict of interests.

\section{References}

Anderson, B., Sharma, N., \& Wright, C. (2012). 'We are all foreigners' no borders as a practical political project. In P. Nyers \& K. Rygiel (Eds.), Citizenship, migrant activism and the politics of movement (pp. 73-92). New York: Routledge.

Ataç, I., Rygiel, K., \& Stierl, M. (2016). Introduction: The contentious politics of refugee and migrant protest and solidarity movements: remaking citizenship from the margins. Citizenship Studies, 20(5), 527-544.

Blumberg, R., \& Rechitsky, R. (2015). Networks, place and barriers to cross-border organizing: "No border" camping in transcarpathia, Ukraine. In J. Mendez Bickham \& N. A. Naples (Eds.), Border politics. Social movements, collective identities and globalization (pp. 293-322). New York and London: New York University Press.

Boatcă, M. (2015). Exclusion through citizenship. Digital Development Debates. Retrieved from http:// www.digital-development-debates.org/issue-14-move ment-moving-people-exclusion-through-citizenship. html

Boggs, C. (1977). Revolutionary process, political strategy, and the dilemma of power. Theory and Society, 4(3), 359-393.

Burridge, A. (2010). Youth on the line and the no borders movement. Children's Geographies, 8(4), 401-411.

Burridge, A. (2015). No borders as a critical politics of mobility and migration. ACME: An International Journal for Critical Geographies, 13(3), 463-470.

Cissé, M. (1996). The sans-papiers: A woman draws the first lessons. Retrieved from http://www.bok.net/ pajol/madjiguene2.en.html

Clarke, A. E. (2005). Situational analysis. Grounded theory after the postmodern turn. Thousand Oaks: Sage Publications Inc.
English, C. (2017). Security is no accident: Considering safe $(r)$ spaces in the transnational migrant solidarity camps of Calais. In G. Brown, A. Feigenbaum, \& F. Frenzel (Eds.), Protest camps in international context: Spaces, infrastructures and media of resistance (pp. 353-370). Bristol: Policy Press.

Hess, S., \& Tsianos, V. (2010). Ethnographische grenzregimeanalysen. Eine methodologie der autonomie der migration. In S. Hess \& B. Kasparek (Eds.), Grenzregime. Diskurse, praktiken, Institutionen in Europa (pp. 243-264). Berlin: Assoziation A.

Jakob, C. (2016). Die bleibenden: Wie flüchtlinge deutschland seit 20 Jahren verändern. Berlin: Ch. Links Verlag.

Juris, J. S., \& Khasnabish, A. (2013). The possibilities, limits and relevance of engaged ethnography. In J. S. Juris \& A. Khasnabish (Eds.), Insurgent encounters. Transnational activism, ethnography and the political (pp. 367-391). Durham and London: Duke University Press.

King, N. (2016). No borders: The politics of immigration control and resistance. London: Zed Books.

Klotz, S. (2016). Selbstorganisation von asylsuchenden: Teilhabeforderungen durch zuwanderung. Forschungsjournal Soziale Bewegungen, 29, 60-69.

Kopp, H., \& Schneider, F. (n.d.). A brief history of the noborder network. Retrieved from http://www. tacticalmediafiles.net/articles/3332/A-Brief-Historyof-the-Noborder-Network

Lang, S., \& Schneider, F. (n.d.). The dark side of camping. Retrieved from http://www.tacticalmediafiles.net/ articles/3338/The-dark-side-of-Camping

Linkes Grafikarchiv. (n.d.). Retrieved from http:// antifagrafik.blogsport.eu

Loyd, J. M., Mitchelson, M., \& Burridge, A. (2012). Introduction. In A. Burridge, M. Mitchelson, \& J. M. Loyd (Eds.), Geographies of justice and social transformation. Beyond walls and cages. Prisons, borders, and global crisis (pp. 1-15). University of Georgia Press.

Millner, N. (2011). From "refugee" to "migrant" in Calais solidarity activism: Re-staging undocumented migration for a future politics of asylum. Political Geography, 30(6), 320-328.

Mudu, P., \& Chattopadhyay, S. (Eds.). (2017). Migration, squatting and radical autonomy. London and New York: Routledge.

Omwenyeke, S. (2016). The emerging welcome culture: Solidarity instead of paternalism. Retrieved from http://www.thevoiceforum.org/node/4155

Rigby, J., \& Schlembach, R. (2013). Impossible protest: Noborders in Calais. Citizenship Studies, 17(2), 157-172.

transact. (2014). Transact! How is your liberation bound up with mine? Retrieved from https://linksunten. indymedia.org/de/system/files/data/2014/02/12255 89416.pdf

Tyler, I., \& Marciniak, K. (2013). Immigrant protest: An introduction. Citizenship Studies, 17(2), 143-156. 
Walia, H. (2013). Introduction. In H. Walia (Ed.), Undoing border imperialism (pp. 1-21). Oakland: AK Press.

Wallrodt, I. (2015, September 23). Ein antifa-logo erobert die herzen. Neues Deutschland.

Walters, W. (2006). No border: Games with(out) fron- tiers. Social Justice, 33(1), 21-39.

Yanow, D., \& Schwartz-Shea, P. (2013). Interpretation and method. Empirical research methods and the interpretative turn (2nd ed., pp. xiii-xxxi). London, New York: Routledge.

\section{About the Author}

Leslie Gauditz is a research assistant at the SOCIUM Research Center on Inequality and Social Policy, University of Bremen, Germany. Her research interest lies in social movements, social conflicts, and alternative economies. She is a political sociologist specializing in qualitative research. 